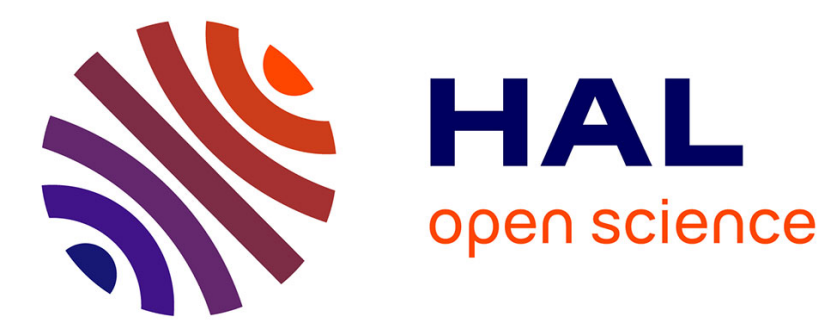

\title{
Continuous-fiber-reinforced thermoplastic composites: influence of processing on fire retardant properties
}

Qing Lin, Michel Ferriol, Marianne Cochez, Henri Vahabi, Christelle Vagner

\section{To cite this version:}

Qing Lin, Michel Ferriol, Marianne Cochez, Henri Vahabi, Christelle Vagner. Continuous-fiberreinforced thermoplastic composites: influence of processing on fire retardant properties. Fire and Materials, 2017, 41 (6), pp.646-653. 10.1002/fam.2406 . hal-01375503

\section{HAL Id: hal-01375503 \\ https://hal.univ-lorraine.fr/hal-01375503}

Submitted on 4 Oct 2016

HAL is a multi-disciplinary open access archive for the deposit and dissemination of scientific research documents, whether they are published or not. The documents may come from teaching and research institutions in France or abroad, or from public or private research centers.
L'archive ouverte pluridisciplinaire HAL, est destinée au dépôt et à la diffusion de documents scientifiques de niveau recherche, publiés ou non, émanant des établissements d'enseignement et de recherche français ou étrangers, des laboratoires publics ou privés. 


\title{
Continuous-fiber-reinforced thermoplastic composites: influence of processing on fire retardant properties
}

\author{
Qing Lin $^{1}$, Michel Ferriol ${ }^{1}$, Marianne Cochez ${ }^{1}$, Henri Vahabi* ${ }^{1}$, Christelle Vagner ${ }^{1,2}$ \\ ${ }^{1}$ Université de Lorraine, LMOPS-EA 4423, Metz, F-57070, France \\ ${ }^{2}$ Aix Marseille Univ, CNRS, MADIREL, Marseille, France \\ *e-mail address: henri.vahabi@univ-lorraine.fr, Telephone: + 33(0)3 879391 86, Fax: + \\ 33(0)387939101
}

\begin{abstract}
Fiber-reinforced thermoplastic composite materials can find numerous applications in the transportation sector and replace thermoset composites. However, they have to comply with strict standards, particularly with those concerning their fire behavior. In this frame, composites based on an acrylic resin Elium $^{\circledR}$ (Arkema), a woven fiberglass, (taffetas tissue Chomarat G-Weave 600 P/A) and Exolit OP930 (Clariant) as fire retardant were prepared using three processes. The thermal stability and fire behavior was studied by means of thermogravimetric analysis and cone calorimetry. The obtained results allowed to highlight the drawbacks of each processing method and to select the most appropriate. The improvement of the fire behavior by combining post-curing of the composites, addition of a cross-linking agent and addition of aluminum trihydroxide (ATH) was also investigated.
\end{abstract}

KEYWORDS: thermoplastic composite, acrylate, flame retardancy, processing, thermal degradation 


\section{INTRODUCTION}

A major concern in the aerospace and automotive industry is weight reduction for fuel economy and minimization of greenhouse gases emission. To meet this challenge, composites based on a polymer matrix reinforced by continuous glass or carbon fibers have been developed in recent years [1]. Several thermoset matrices have been used: epoxies, phenolics, polyesters and polyimides. Each presents one or more drawbacks, including cost, difficulty in processing and non-recyclability. More recently, high-performance thermoplastic resins have been developed, including polyetherimide (PEI), polyphenylene sulfide (PPS), polyether ketone (PEK) and polyether ether ketone (PEEK). PEEK is highly resistant to thermal degradation, but difficult to process and very expensive $[2,3]$.

We have been involved in research whose goal was to develop thermoplastic composites based on easily available and low cost polymers, transformed using the same processes as composite thermosets. Furthermore, to be used in transportation applications, they should exhibit low flammability, heat release and smoke density. From an environmental perspective, they should also be recyclable. As fire retardant compounds are incorporated in the starting monomer, by mixing, the fire behavior can be influenced by the processing method used. The objective of this study was to evaluate the effect of processing method on fire performance properties.

\section{EXPERIMENTAL}

The composites were prepared from a liquid acrylic thermoplastic resin, Elium ${ }^{\circledR}$, provided by Arkema. In addition to the acrylic monomer, the resin contained a peroxide catalyst to initiate the polymerization and an accelerator agent to activate the peroxide catalyst. The reinforcement fibers were a glass taffetas tissue with a sizing agent compatible with acrylic resin (Chomarat G-Weave $600 \mathrm{P} / \mathrm{A}$ ). All samples contained 9 layers of fiber glass. The theoretical fiber volume ratio was about $53 \%$. The fire retardants were incorporated in the liquid resin prior to processing and included an aluminum phosphinate, commercially named as Exolit OP930 from Clariant and aluminum trihydroxide (ATH Martinal OL104IO) from Albemarle Corporation. 
Three processes were used to obtain composites: (1) liquid resin press molding, (2) prepreg followed by thermocompression and (3) a modification of (2), discussed below.

Process 1 consisted of manually impregnating the nine reinforcement layers of woven fiberglass with the filled resin (resin/flame retardant) and polymerizing at room temperature under low pressure (250 $\pm 50 \mathrm{mbar})$. A sheet of about $230 \times 300 \mathrm{~mm}$ and $4 \mathrm{~mm}$ in thickness was prepared. The thickness was based on requirements specified by standard cone calorimeter tests (ISO 5660).

Process 2 was a two-step process. In the first step, a woven fiberglass sheet was manually impregnated with the filled resin. The polymerization was then performed at low pressure (200 mbar) and room temperature. In the second step, the foil was cut into nine sheets stacked and thermocompressed under 15 bars at $200{ }^{\circ} \mathrm{C}$ in order to allow the polymer to flow between the layers and to compact and make cohesive material.

Process 3 was similar to process 2 , but with some modifications. The nine reinforcement layers, always manually impregnated with the filled resin, were stacked and placed into an anti-adhesive polyimide film to prevent any resin flowing during processing. Then, the polymerization was completed at $80{ }^{\circ} \mathrm{C}$ in an hydraulic press under 10 bar pressure.

Prior to investigating the fire behavior, the thermal degradation of the different samples was evaluated by thermogravimetric analysis (TGA) with a Mettler-Toledo TGA/SDTA $851^{\mathrm{e}}$ under air atmosphere. The sample mass was $30-40 \mathrm{mg}$ and the heating rate was $10^{\circ} \mathrm{C} \cdot \mathrm{min}^{-1}$. All TG curves were drawn using the unreacted mass fraction 1- $\alpha$ given by:

$$
1-\alpha=\frac{m_{t}-m_{\infty}}{m_{0}-m_{\infty}}
$$

in which $\mathrm{m}_{0}$ was the initial sample weight, $\mathrm{m}_{\mathrm{t}}$ was the residual sample weight at time $\mathrm{t}$ and $\mathrm{m}_{\infty}$ was the residual weight at infinite time. The DTG curves were expressed as $d \alpha / \mathrm{dt}$. The dispersion state of flame retardant particles was evaluated using elemental mapping (on $1 \times 1 \mathrm{~mm}$ surface of sample) by X-ray fluorescence (XGT-7000 Horiba Jobin-Yvon) and scanning electron microscope/energy-dispersive X-ray spectroscopy (SEM/EDS-QuantaFeg 200/Genesis 4i). The fire behavior was evaluated using a cone calorimeter FIRE-EU 
(ISO 5660). The sample size was $100 \times 100 \times 4 \mathrm{~mm}$ and the heat flux was $35 \mathrm{~kW} \cdot \mathrm{m}^{-2}$. The cone calorimeter was the most appropriate device to simulate a well ventilated fire scenario [4]. Several parameters were simultaneously measured, including heat release rate (HRR), time to ignition (TTI), total heat released (THR), maximum (peak) of heat release rate (pHRR), time of flame-out, mass loss, smoke density, $\mathrm{CO}$ and $\mathrm{CO}_{2}$ amounts. To evaluate the fire properties, pHRR was used as it characterizes the propagation rate of the flame and the spreading of fire [5]. For each process and fire retardant composition, two experiments were performed. Accuracy is estimated to be around 5\% in cone calorimeter tests [6]. The results given were the mean of, at least, two consistent experiments. Limiting Oxygen Index (LOI) tests were carried out using a FTT Company instrument, ISO4589. The dimensions of specimens were $6 \times 10 \times 4 \mathrm{~mm}$. UL-94 vertical burn tests were performed on the samples having a dimension of $100 \times 6.5 \times 4 \mathrm{~mm}$ [7].

\section{RESULTS AND DISCUSSION}

As the basis of the three forming processes considered in this work is the manual impregnation of the reinforcement tissue with the filled resin, the dispersion state of the fire retardant particles in the composite was checked by X-ray fluorescence and SEM/EDS mapping (based on phosphor), Figure 1 and 2, respectively. These figures give an example of dispersion state for a composite filled with $15 \mathrm{phr}$ (parts per hundred of resin), of Exolit flame retardant. The dispersion of the flame retardants particles $\left(\mathrm{d}_{50}=2.5 \mu \mathrm{m}\right)$ was satisfactory with some aggregates. 


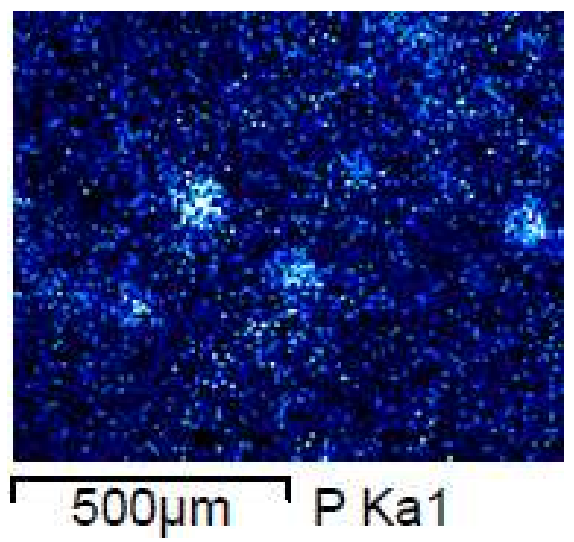

Fig 1. Image obtained by X-ray Fluorescence mapping.
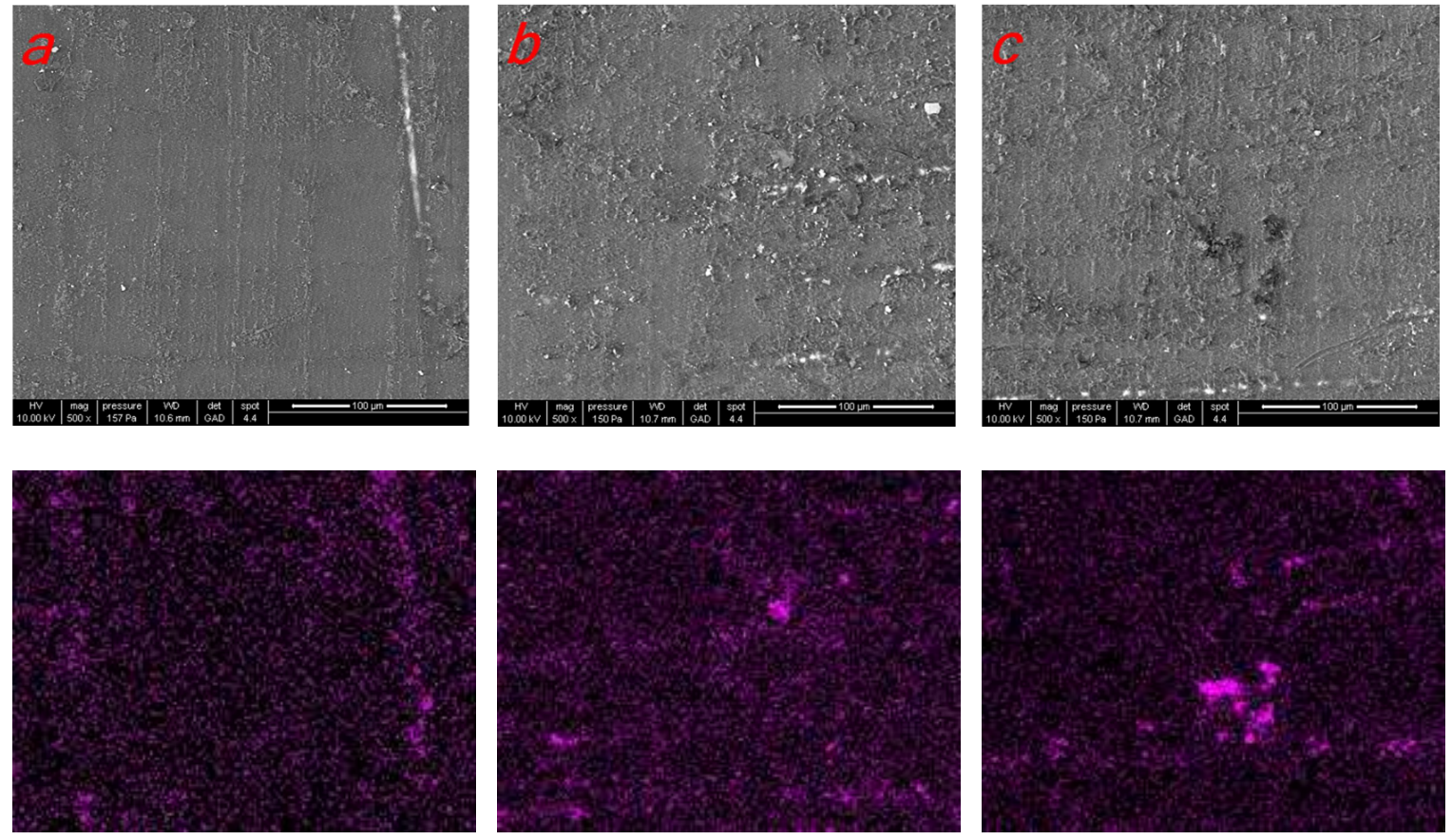

Fig 2. SEM (a,b,c) and EDS mapping images.

\section{Thermal degradation}

Regardless the forming process used, the DTG curves of all composites exhibited three peaks corresponding to different steps of degradation. The TG and DTG curves obtained for samples prepared with the three forming processes and containing 15, 20 and $25 \mathrm{phr}$ of OP930 are shown in Figure 3. The recorded DTG peak temperatures for each process and 
loading amount are given in Table 1 . The best thermal stability was obtained with $25 \mathrm{phr}$ of OP930, except for process 1 .

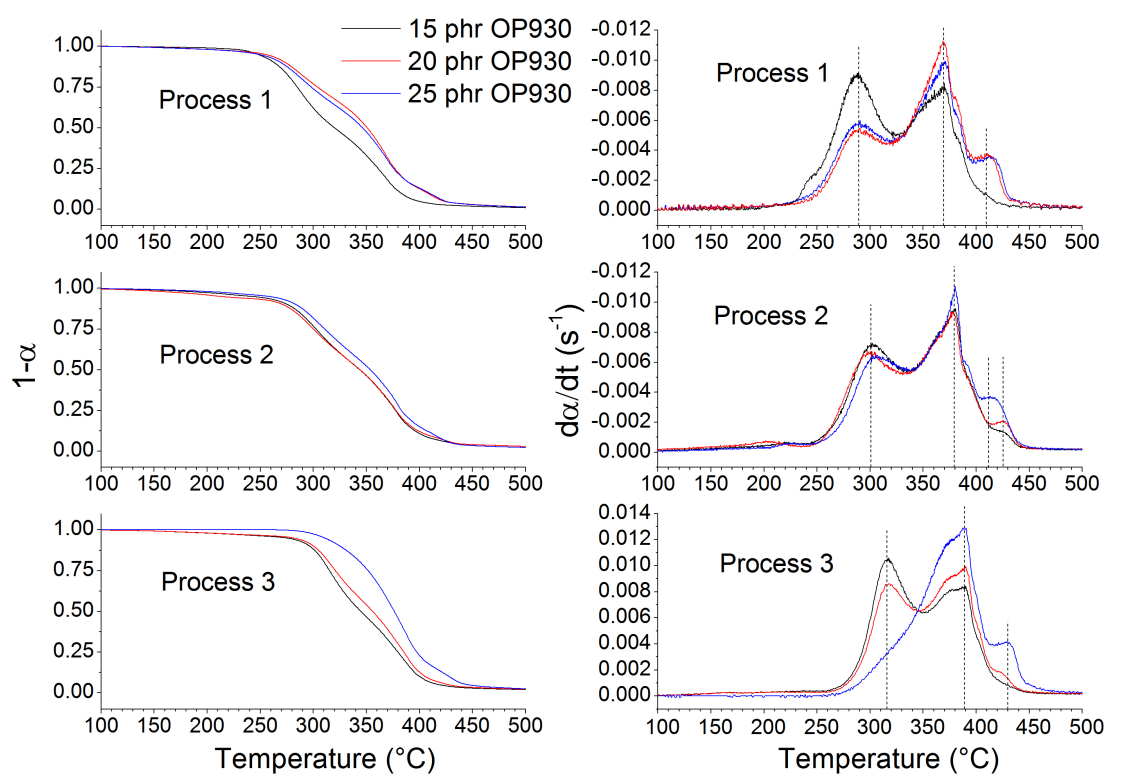

Fig 3. TG and DTG curves for all samples obtained with the three forming processes (left: TG curves, right: corresponding DTG curves).

Table 1. Temperatures of DTG peaks for each forming process.

\begin{tabular}{|c|c|c|c|}
\hline Process & Peak $1\left({ }^{\circ} \mathrm{C}\right)$ & Peak $2\left({ }^{\circ} \mathrm{C}\right)$ & Peak $3\left({ }^{\circ} \mathrm{C}\right)$ \\
\hline 1 & 290 & 370 & 410 \\
2 & $300-310$ & 380 & $412-423$ \\
3 & 316 & 389 & 430 \\
\hline
\end{tabular}

From processes, 1 to 3 , the composites appear increasingly more stable as shown by the increasing temperature of each peak (Table 1).

For a given forming process, increasing fire retardant amount should be accompanied by an increased thermal stability and therefore by a significative shift of mass loss curves towards higher temperatures. This is clearly observed for process 3 but not for processes 1 and 2. As shown in Figure 3, for process 1, the curves obtained for 20 and $25 \mathrm{phr}$ are very close (shifted by less than $5{ }^{\circ} \mathrm{C}$ at half-degradation (50\% mass loss (T50\%)) and shifted by $30{ }^{\circ} \mathrm{C}$ from the $15 \mathrm{phr}$ curve. In the case of process 2 and for 15 and $20 \mathrm{phr}$ of OP930, the curves are practically merged and for $25 \mathrm{phr}$, a shift of about $5{ }^{\circ} \mathrm{C}$ was observed at half- 
degradation. For process 3, at half-degradation, the mass loss curves are shifted by $9{ }^{\circ} \mathrm{C}$ for $20 \mathrm{phr}$ towards $15 \mathrm{phr}$ and $16{ }^{\circ} \mathrm{C}$ for $25 \mathrm{phr}$ towards $20 \mathrm{phr}$. To explain the relative positions of the observed TG and DTG curves when the fire retardant amount increased, one can suppose that the sample preparation for TG analysis affected the results when a small part (30-40 mg) of the composite is cut in the bulk sample. Therefore, the homogeneity and composition of resin/fiber could be different in a small sample than in the composite. It was also observed in the DTG curves for process 3 that the loading of $25 \mathrm{phr}$ of OP930 influenced the first step of degradation compared to the other processes and loading percentages.

\section{Cone calorimeter tests}

Table 2 gives the values of pHRR, THR and TTI measured for each forming process and for the different OP930 compositions. Figure 4 gives the corresponding HRR curves. It appears that samples obtained by process 1 have the lowest total heat released (THR) and the highest time to ignition (TTI) whereas it is practically the same for samples prepared by processes 2 or 3 . Considering the procedure used in process 1 , one can assume that the low pressure applied during the polymerization step results in some evaporation of the monomer, according to the vapor pressure of parent acrylic monomers [8], leading to a concentration of the fire retardant (non-volatile) in the polymerized material. Then, the samples obtained from process 1 should be more concentrated in OP930 than the samples produced by process 2 or 3 . Consequently, they are thermally more stable and therefore, ignition would be delayed. Since they would also contain less combustible material, the released heat would be lower. These two facts were experimentally observed (Table 2). 
Table 2. Cone calorimeter results for each forming process

\begin{tabular}{|l|c|c|c|c|}
\hline & OP930 amount $(\mathrm{phr})$ & $\mathrm{pHRR}\left(\mathrm{kW} \cdot \mathrm{m}^{-2}\right)^{*}$ & THR $\left(\mathrm{MJ} \cdot \mathrm{m}^{-2}\right)^{*}$ & TTI $(\mathrm{s})^{*}$ \\
\hline \multirow{3}{*}{ Process 1 } & 15 & 190 & 31 & 56 \\
& 20 & 155 & 18 & 76 \\
& 25 & 158 & 24 & 75 \\
\hline \multirow{3}{*}{ Process 2 } & 15 & 315 & 45 & 34 \\
& 20 & 267 & 47 & 48 \\
& 25 & 169 & 63 & 50 \\
\hline \multirow{3}{*}{ Process 3 } & 15 & 157 & 37 & 42 \\
& 20 & 159 & 31 & 45 \\
\hline
\end{tabular}

* These results are the mean of two values, obtained from two tests on each sample.

For process 2, the shape of all curves in Figure 4 is different than those obtained for the two other processes. Several peaks can be seen, meaning successive extinctions and re-ignitions after the first ignition. This behavior can be interpreted by considering a delamination of the different layers under the action of heat and the formation of cavities of combustible gases between them, abruptly released as the combustion advances through the sample. This would permit succession of ignitions and partial extinctions. In these conditions, the HRR curves present several peaks as confirmed in the literature [9]. 

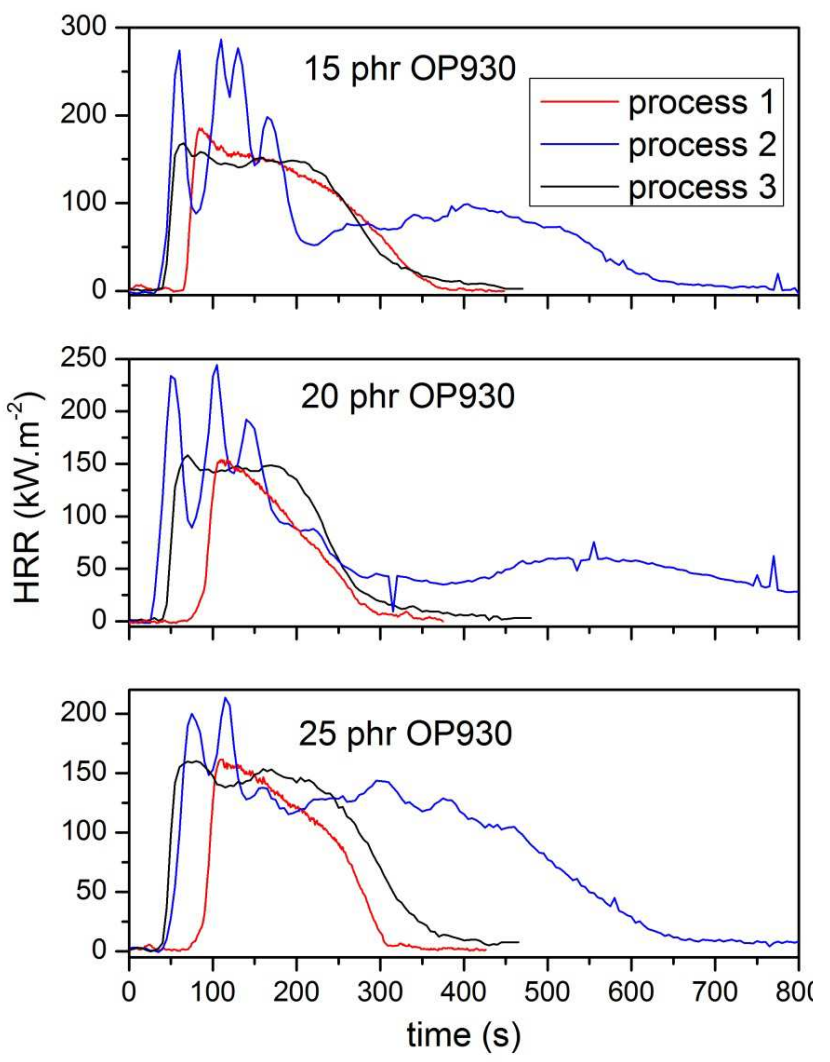

Fig 4. Comparison of HRR curves for the three forming processes.

This drawback does not exist in process 3 as the process ensures a good interpenetration of macromolecular chains between the reinforcement layers and good cohesion of the composite. The composites obtained with this process demonstrate an improved fire performance than those produced with process 2 , but slightly worse than those prepared with process 1 . This result is logical as those obtained for samples produced with process 1 were overestimated due to the evaporation of the resin during processing.

The forming process 3 resolved the encountered problems including loss of material by evaporation (process 1), lack of homogeneity and lack of densification of the different layers (process 2). It allowed production of reliable samples for deeper investigation of their fire behavior. 


\section{Improvement of fire behavior}

The best forming process being designed (process 3), and the composite containing $20 \mathrm{phr}$ of OP930 exhibiting the best results in the cone calorimeter test, we focused on improving the fire performance of this composite by considering three options:

(1) adding aluminum trihydroxide (ATH), which has been shown to improve the fire retardant properties of PMMA, an acrylate polymer of the same family as that investigated during this work [10].

(2) addition of $2 \mathrm{phr}$ of dibutylmaleate (DBMA), a cross-linking agent, to improve the thermal stability as previously reported in the literature for a similar polymer and crosslinking agent (PMMA/2 phr of divinylbenzene) [11].

(3) after manufacturing, heating of the processed samples to $200{ }^{\circ} \mathrm{C}$ for 30 minutes to complete the polymerization reaction.

The loading amount was fixed at $20 \mathrm{phr}$ after LOI and vertical UL-94 tests of different OP930/ATH compositions. These results are summarized in Table 3. The best result was obtained by combining $30 \mathrm{phr}$ OP930 and $10 \mathrm{phr}$ of ATH. However because of cost considerations (OP930 is more expensive than ATH), the loading amount of $20 \mathrm{phr}$ OP930 and $20 \mathrm{phr}$ of ATH was selected. Furthermore, this loading also allowed us to keep a ratio of 2 between aluminum and phosphorus which corresponds to the best results in terms of fire retardancy, as reported by Duquesne et al. [12].

Table 3. LOI and UL-94 results for composites obtained by process 3 and containing OP930 and ATH.

\begin{tabular}{|c|c|c|c|}
\hline \multicolumn{2}{|c|}{ Flame retardant (phr) } & \multirow{2}{*}{ LOI (\%) } & \multirow{2}{*}{ UL-94 } \\
\cline { 1 - 2 } OP930 & ATH & & \\
\hline 25 & 0 & 45 & V-1 \\
\hline 15 & 10 & 43 & V-1 \\
\hline 10 & 15 & 36 & NC $*$ \\
\hline 0 & 25 & 25 & NC \\
\hline 40 & 0 & 48 & V-1 \\
\hline 30 & 10 & 53 & V-1 \\
\hline 20 & 20 & 45 & V-1 \\
\hline 10 & 30 & 38 & NC \\
\hline 0 & 40 & 27 & NC \\
\hline
\end{tabular}

* NC: Not Classified 
Table 4 gives the different combinations studied by cone calorimetry. Table 5 and Figure 5 summarize the results. They show that the addition of ATH, alone and without post-curing, results in the reduction of pHRR by $13 \%$ and for THR by $26 \%$, which confirms the positive influence of this fire retardant for acrylate-based polymers. In all cases with no DBMA addition, the results indicated that post-curing allowed further improvement of the fire behavior: pHRR was additionally decreased by $7 \%$ whereas TTI increased from 50 to $59 \mathrm{~s}$ but THR remains unchanged. With the addition of DBMA, time to ignition increased from 50 to 68 and 74 s (36\% and $48 \%$ ) without and with post-curing. This confirmed the increased thermal stability of the polymer when a cross-linking agent was added before polymerization. Regarding the accuracy on pHRR value (10\%), there was no supplementary effect from the cross-linking agent. With post-curing, it increased from 127 to $150 \mathrm{~kW} \cdot \mathrm{m}^{-2}(18 \%)$ and without post-curing, it increased from 136 to $154 \mathrm{~kW} \cdot \mathrm{m}^{-2}$ (13 $\%)$. At the same time, the total heat released increased from 23 to $27 \mathrm{MJ} . \mathrm{m}^{-2}$ (17\%) without post-curing and when post-curing was performed, THR increased from 24 to $28 \mathrm{MJ} \cdot \mathrm{m}^{-2}$ (17 $\%)$. This can be interpreted by considering that DBMA promotes the combustion of the acrylate-based polymers.

Table 4. Composition of the different combinations studied involving ATH, DBMA and postcuring.

\begin{tabular}{|c|c|c|c|}
\hline \multicolumn{3}{|c|}{ Loading amount (phr) } & Post-curing \\
\hline OP930 & ATH & DBMA & \\
\hline 20 & 20 & 0 & Yes \\
20 & 20 & 0 & No \\
20 & 20 & 2 & Yes \\
20 & 20 & 2 & No \\
\hline
\end{tabular}

Table 5. Cone calorimeter results for samples with ATH, DBMA and post-curing.

\begin{tabular}{|c|c|c|c|c|}
\hline $\begin{array}{c}\text { OP930/ATH/DBMA } \\
(\mathrm{phr})\end{array}$ & Post-curing & $\begin{array}{c}\text { pHRR* } \\
\left(\mathrm{kW} . \mathrm{m}^{-2}\right)\end{array}$ & $\begin{array}{c}\text { THR }^{*} \\
\left({\mathrm{MJ} . \mathrm{m}^{-2}}^{-2}\right.\end{array}$ & TTI (s)* \\
\hline $20 / 0 / 0$ & No & 157 & 31 & 45 \\
$20 / 20 / 0$ & No & 136 & 23 & 50 \\
$20 / 20 / 2$ & No & 154 & 27 & 68 \\
$20 / 20 / 0$ & Yes & 127 & 24 & 59 \\
$20 / 20 / 2$ & Yes & 150 & 28 & 74 \\
\hline
\end{tabular}

* These results are the mean of two values, obtained from two tests on each sample. 


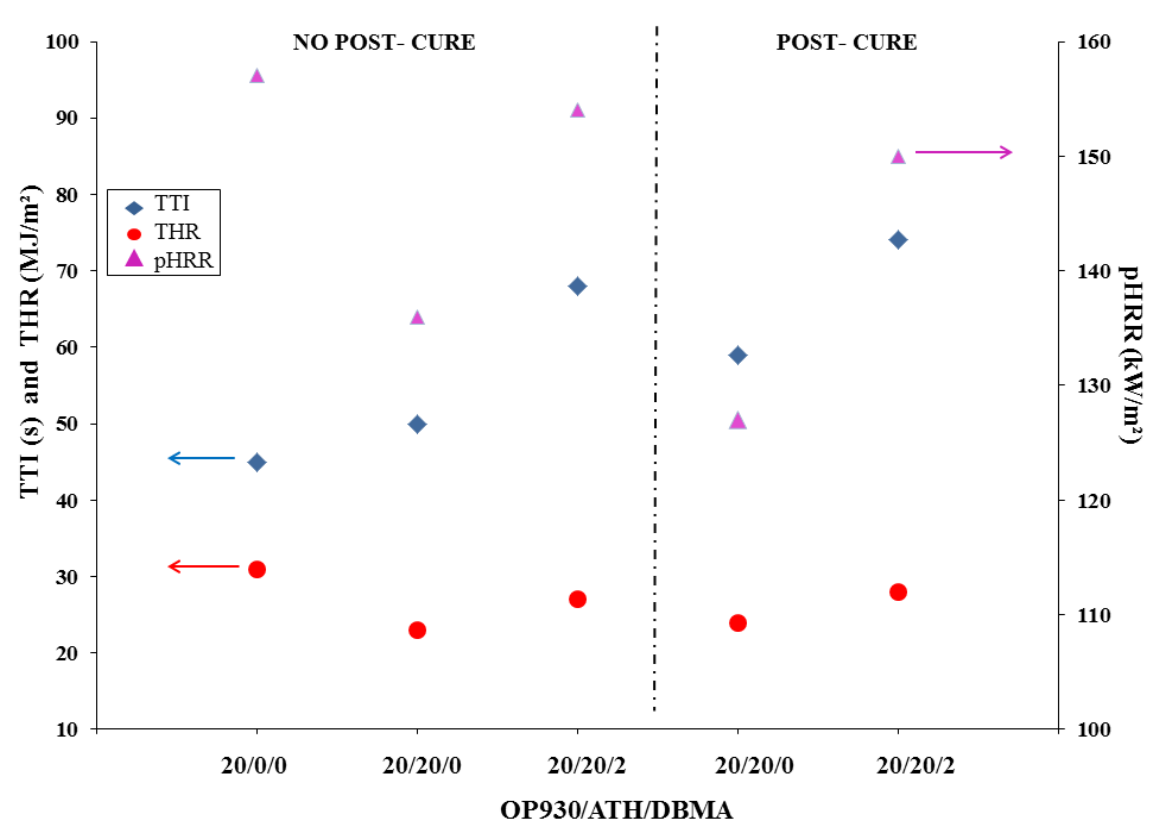

Fig 5. Comparison of cone calorimeter results for samples involving ATH, DBMA and post-curing.

\section{CONCLUSION}

In this study, three different forming processes were used to prepare samples of acrylate resin/taffetas/OP930. The results got with the cone calorimeter test made it possible to identify the disadvantages of each process and to select the best one: process 3 . Results showed that fire behavior was improved by adding ATH and post-curing of the composites contrary to the addition of the cross-linking agent (DBMA) which did not bring significant effect. These results will be useful to define an automated process leading to an optimized fire behavior of industrial parts.

\section{ACKNOWLEDGMENTS}

The authors want to thank PPE (Pôle de Plasturgie de 1'Est, Saint-Avold, France) for the manufacturing of composites and the Région Lorraine for financial support in the frame of the "Résines idéales" collaborative research program. 


\section{REFERENCES}

1. Nayak, N.V.: Composite Materials in Aerospace Applications. IJSRP 4, 1-10, (2014)

2. Patel P., Hull T.R., Lyon R.E., Stoliarov S.I., Walters R.N., Crowley S., Safronava N.: Investigation of the thermal decomposition and flammability of PEEK and its carbon and glass-fibre composites. Polym. Degrad. Stab. 96, 12-22, (2011)

3. Patel P., Stec A.A., Hull T.R., Naffakh M., Diez-Pascual A.M., Ellis G., Safronava N., Lyon R.: Flammability properties of PEEK and carbon nanotube composites. Polym. Degrad. Stab. 97, 2492-2502, (2012)

4. Brabauskas V., Peacock R.D.: Heat release rate: The single most important variable in fire hazard. Fire Safety J. 18, 255-272, (1991)

5. Ferriol M., Laoutid F., Lopez-Cuesta J.M.: Fire retardancy of multiphase polymer systems, chapter 22 in: Handbook of multiphase polymer systems, Fisrt edition, edited by A. Boudenne, L. Ibos, Y. Candau and S. Thomas, John Wiley \& Sons, 843-864 (2011)

6. Hugget C., Estimation of Rate of Heat Release by Means of Oxygen Consumption Measurements, Fire and Materials, 4, 2, 61-65, (1980)

7. UL-94- Test for Flammability of Plastic Materials for Parts in Devices and Appliances, Fifth Edition, Underwriters Laboratories Inc. ISBN 0-7629-0082-2, (1996)

8. Lide D.R., Kheiaian H.V.: CRC Handbook of Thermophysical and Thermochemical Properties, CRC Press (1994).

9. Schartel B., Hull T.R.: Development of fire-retarded materials-Interpretation of cone calorimeter data. Fire Mater. 31, 327-354, (2007)

10. Bundersek A., Japelj B., Music B., Rajnar N., Gyergyek S., Kostanjsek R. Krajnc P.: Influence of $\mathrm{Al}(\mathrm{OH})_{3}$ nanoparticles on the mechanical and fire resistance properties of poly(methyl methacrylate) nanocomposites. Polym. Composite. 37, Issue 6, 1659-1666, (2016)

11. Uhl F.M., Levchik G.F., Levchik S.V., Dick C., Liggat J.J., Snape C.E.,Wilkie C.A.: The thermal stability of cross-linked polymers: methyl methacrylate with divinylbenzene and styrene with dimethacrylates. Polym. Degrad. Stab.71, 317-325, (2001)

12. Duquesne S., Fontaine G., Cérin-Delaval O., Fontaine G., Gardelle B., Tricot G., Bourbigot S.: Study of the thermal degradation of an aluminium phosphinate-aluminium trihydrate combination. Thermochimica Acta 551, 175-183, (2013) 